\title{
Pengaruh Model Pembelajaran Kooperatif Tipe Number Heads Together (NHT) Terhadap Hasil Belajar Sejarah
}

\author{
Oleh : Eka Sari Handayani \\ Pendidikan Sejarah PPS UNJ
}

\begin{abstract}
This research aims to determine the effect of cooperative learning model type Numbered Head Together (NHT) toward learning history outcomes at SMA Negeri 3 Kabupaten Tangerang. This research is quantitative approach with experimental method. From the result of statistical calculation, it can be concluded that there is a significant effect in cooperative learning model type Numbered Head Together (NHT) toward learning history outcomes which come out from tcount value 5,961 >ttable 2,00 with significant rate 0,05 .
\end{abstract}

Keyword: Cooperative Learning Model Type NHT, learning history outcomes

\begin{abstract}
Abstrak
Penelitian ini bertujuan untuk mendapatkan data empiris tentang pengaruh model pembelajaran kooperatif tipe Number Heads Together (NHT) terhadap hasil belajar sejarah di SMA Negeri 3 Kabupaten Tangerang. Pendekatan penelitian yang digunakan adalah pendekatan kuantitatif dengan metode eksperimen. Dari hasil perhitungan statistik dapat disimpulkan bahwa terdapat pengaruh positif dan signifikan penggunaan model pembelajaran kooperatif tipe Numbered Head Together (NHT) terhadap hasil belajar sejarah yang dibuktikan dari menghasilkan thitung 5,961 > ttabel 2.00 pada taraf kepercayaan 95\% ( $\alpha=0,05$.
\end{abstract}

Kata Kunci: Model pembelajaran kooperatif, NHT, hasil belajar, sejarah

\section{PENDAHULUAN}

Pembelajaran merupakan serangkaian proses kegiatan yang melibatkan guru dan siswa yang mengacu pada sumber belajar dalam sebuah lingkungan belajar. Dalam proses pembelajaran, guru dan siswa merupakan dua komponen inti yang tidak bisa dipisahkan. Antara kedua komponen inti tersebut harus terjalin komunikasi multiarah yang bersifat edukatif. Dalam makna yang lebih kompleks, pembelajaran pada hakikatnya menurut Trianto (2009:17) adalah suatu usaha sadar dari seorang guru untuk membelajarkan siswanya dalam rangka mencapai tujuan yang diharapkan.
Keberhasilan dalam sebuah proses pembelajaran tersebut dapat dilihat melalui hasil belajar siswa yang ditandai dengan adanya perubahan pada diri siswa yang meliputi beberapa aspek yakni aspek pengetahuan, pemahaman, keterampilan, nilai dan juga sikap yang didapat siswa dari latihan atau pengalaman belajarnya. Hasil belajar merupakan alat untuk mengukur sejauh mana siswa telah menguasai materi yang diajarkan oleh guru. Menurut Sudjana (2011:22), hasil belajar adalah kemampuan-kemampuan yang dimiliki siswa setelah ia menerima pengalaman belajarnya. Hasil peristiwa belajar dapat muncul dalam berbagai jenis perubahan atau pembuktian tingkah laku 
seseorang.Oleh karena itu, hasil belajar merupakan faktor penting dalam sebuah proses pembelajaran.

Menurut Carol yang dikutip Sudjana (2005:40), hasil belajar siswa dipengaruhi oleh lima faktor, yaitu a.) bakat siswa, b.) waktu yang tersedia untuk belajar, c.) waktu yang diperlukan siswa untuk menyelesaikan pelajaran, d.) kualitas pembelajaran, dan e.) kemampuan siswa. Oleh karena itu, pencapaian hasil belajar tidak hanya tergantung pada kemampuan dan bakat siswa secara personal, namun juga harus didukung dari faktor eksternal, yakni lingkungan dan kemampuan guru dalam menyajikan materi sehingga pembelajaran dapat berlangsung efektif dan efisien.

Hasil belajar dapat diukur antara lain dengan melakukan tes di akhir penyampaian materi pelajaran yang diwujudkan dalam pemberian nilai. Umumnya ranah kognitif yang dipakai dalam menilai kemampuan siswa di sekolah. Hasil belajar dalam penelitian ini adalah hasil belajar yang merupakan kemampuan yang didapat setelah mengalami proses pembelajaran. Perubahan kemampuan berupa kemampuan kognitif yang meliputi pengetahuan, pemahaman dan aplikasi menjadi objek penelitian yang lebih ditekankan. Untuk mengetahui tingkat pengetahuan yang telah diperoleh peneliti akan melihatnya melalui tes hasil belajar.

Menurut Trianto (2009:5), masalah utama dalam pembelajaran pada pendidikan formal (sekolah) dewasa ini adalah masih rendahnya daya serap siswa. Hal ini tampak dari rerata hasil belajar siswa yang masih senantiasa memprihatinkan. Prestasi ini tentunya merupakan hasil kondisi pembelajaran yang masih bersifat konvensional dan tidak menyentuh ranah dimensi siswa itu sendiri. Dalam arti yang lebih substansial, bahwa proses pembelajaran hingga dewasa ini masih memberikan dominasi guru dan tidak memberikan akses bagi siswa untuk berkembang secara mandiri melalui penemuan dalam proses berpikirnya.

Menurut Kuntowijoyo (2005:18), sejarah merupakan rekonstruksi masa lalu. Maka sejarah diharapkan dapat memberikan pedoman di masa depan melalui rekonstruksi masa lalu. Adapun menurut Subakti (2010: 4), pembelajaran sejarah adalah pembelajaran yang mampu menumbuhkan kemampuan siswa dalam melakukan konstruksi kondisi masa sekarang dengan mengkaitkan atau melihat masa lalu yang menjadi basis topik pembelajaran sejarah. Kontekstualitas sejarah harus kuat mengemuka dan berbasis pada pengalaman pribadi para siswa. Apalagi sejarah tidak akan terlepas dari konsep waktu, kontinuitas dan perubahan. Belajar sejarah berarti siswa mampu berpikir kritis dan mampu mengkaji setiap perubahan di lingkungannya, serta memiliki kesadaran akan perubahan dan nilai-nilai yang terkandung dalam setiap peristiwa sejarah.

Berdasarkan tujuan pendidikan Nasional, mata pelajaran sejarah secara ideal bertujuan agar siswa mampu meningkatkan pemahaman sejarah secara kronologis, menganalisis serta mengkritisi suatu kejadian atau peristiwa masa lalu sehingga dapat membentuk watak berpikir siswa. Namun dalam prakteknya tidak. Menurut Sam Wineburg (2006:ix), kondisi pendidikan sejarah di Indonesia sangat prihatin karena siswa hanya diajarkan menghafal nama dan tahun sehingga kemampuan siswa lemah dalam menganalisis dan mengkritisi kejadian peristiwa sejarah dan berujung pada rendahnya pemahaman sejarah siswa. 
Sehingga pada akhirnya mata pelajaran sejarah dinilai sebagai mata pelajaran yang tidak menarik. Kenyataan yang ditemukan di lapangan juga adalah bahwa proses pembelajaran sejarah di dalam kelas jauh dari kata mudah. Menurut Isjoni dan Ismail (2008: 146), jika pembelajaran sejarah kurang mengikutsertakan siswa maka akan berdampak pada munculnya 'budaya diam' berlangsung di dalam kelas, dan pada akhirnya pembelajaran sejarah kurang begitu menyentuh diri siswa dan lingkungannya. Di pihak lain secara empiris, berdasarkan hasil analisis penelitian terhadap rendahnya hasil belajar siswa disebabkan dominannya proses pembelajaran konvensional atau cenderung teacher-oriented yang mengakibatkan siswa menjadi pasif.

Kelas X IIS merupakan kelas yang menjadi sasaran peneliti karena memiliki masalah belajar yang cukup banyak. Berdasarkan hasil wawancara dan observasi awal yang dilakukan oleh peneliti pada hari Selasa, tanggal 13 Mei 2014 di kelas X IIS SMA Negeri 3 Kabupaten Tangerang terungkap empat masalah antara lain : 1) Keaktifan siswa di kelas dinilai masih kurang, hal ini tampak hanya beberapa orang yang terlihat menjawab dan mengajukan pertanyaan kepada guru. 2) Siswa kurang termotivasi untuk mengikuti pelajaran sejarah karena guru kurang bervariasi dalam penyampaian materi. Guru hanya mengandalkan metode ceramah dalam menyampaikan materi dan jarang sekali menggunakan metode atau model pembelajaran yang lain. 3) Hasil belajar siswa yang kurang. Nilai rata-rata kelas yang didapat siswa pada pelajaran sejarah kelas X IIS adalah 69, padahal nilai standar kelulusan minimum di SMA Negeri 3 Kabupaten Tangerang adalah 75.

Untuk menyikapi hal itu, guru perlu menerapkan perubahan dan inovasi dalam gaya penyampaian materi sejarah di kelas agar dapat meningkatkan minat dan hasil belajar siswa. Salah satunya dengan menerapkan model-model pembelajaran kooperatif. Menurut Sanjaya dalam Hamdani (2011:30), pembelajaran kooperatif merupakan salah satu bentuk pembelajaran yang berdasarkan paham konstruktivisme. Melalui pembelajaran kooperatif, keaktifan siswa dalam pembelajaran di kelas akan lebih terlihat. Interaksi dalam pembelajaran kooperatif akan dapat meningkatkan motivasi rangsangan berpikir siswa sehingga hal ini bertujuan agar minat dan hasil belajar sejarah siswa dapat meningkat secara maksimal.

Seperti yang dikemukakan dimuka pada bab IV Pasal 19 Peraturan Pemerintah No. 19 Tahun 2005 dikatakan bahwa proses pembelajaran pada satuan pendidikan diselenggarakan secara interaktif, inspiratif, menyenangkan, menantang, memotivasi siswa untuk berpartisipasi aktif serta memberikan ruang yang cukup bagi prakarsa, kreativitas dan kemandirian sesuai dengan bakat, minat dan perkembangan fisik serta psikologis peserta didik. Hal ini menunjukan bahwa mengajar yang didesain guru harus berorientasi pada aktivitas siswa.

Model pembelajaran yang tepat diterapkan dalam mata pelajaran sejarah haruslah model yang sederhana tetapi mudah untuk dipahami siswa. Peneliti beranggapan bahwa model pembelajaran yang menarik dan tepat diterapkan sesuai dengan karakteristik siswa X IIS adalah model pembelajaran kooperatif tipe Number Heads Together (NHT). Model pembelajaran NHT menurut Isjoni (2007: 15) merupakan salah satu dari pendekatan pembelajaran kooperatif dimana sistem belajar dan bekerja dalam kelompok- 
kelompok kecil yang berjumlah empat hingga enam orang secara kolaboratif sehingga dapat merangsang siswa lebih bergairah dalam belajar. Menurut Trianto (2009: 82) NHT merupakan jenis pembelajaran kooperatif yang dirancang untuk mempengaruhi pola interaksi siswa dan sebagai alternatif terhadap struktur kelas tradisional. Lie (2005:59) menyatakan bahwa NHT merupakan model yang dapat memberikan kesempatan kepada siswa untuk saling membagikan ide-ide dan mempertimbangkan jawaban yang paling tepat.Selain itu juga mendorong siswa untuk meningkatkan semangat kerjasama mereka. Model ini bisa digunakan dalam semua mata pelajaran dan untuk semua tingkatan usia anak didik.

Adapun berikut langkah-langkah pembelajaran yang harus diterapkan dalam menggunakan model pembelajaran NHT seperti yang dikutip Nurhadi (2005:21):

1.) Langkah pertama adalah penomoran (Numbering), guru membagi siswa kedalambeberapa kelompok yang beranggotakan empat hingga enam orang dan setiap anggota kelompok diberi nomor satu hingga enam penomoran dilakukan untuk mengklasifikasikan tugas-tugas individu setiap siswa.

2.) Langkah kedua adalah mengajukan pertanyaan (Questioning): Guru memberikan tugas-tugas baik berupa pertanyaan atau arahan yang harus dikerjakan oleh setiap anggota kelompok. Pertanyaan yang diajukan bervariasi dimulai dari yang sederhana hingga yang kompleks.

3.) Langkah ketiga adalah berpikir bersama (Heads Together): Siswa berpikir bersama dan menyatukan jawaban pertanyaan itu serta meyakinkan tiap anggota dalam kelompoknya mengetahui jawaban itu. Heads Together yang dimaksudkan adalah kepala kelompok dimana setiap siswa dalam kelompok untuk meyakinkan jawaban yang diperolehnya kepada semua anggota kelompoknya.

4.) Langkah keempat adalah menjawab (Answering): Guru memanggil satu nomor tertentu untuk menjawab pertanyaan yang diajukan, kemudian siswa yang nomornya sesuai dari tiap kelompok mengacungkan tangannya dan mencoba untuk menjawab pertanyaan dalam kelas sehingga jawaban diketahui oleh seluruh siswa.

Model pembelajaran NHT apabila dijalankan sesuai langkah-langkah diatas akan mewujudkan hasil belajar yang baik dan maksimal. Dengan langkah-langkah tertentu yang membuat siswa aktif dalam mengemukakan pendapat-pendapatnya melalui hasil diskusinya. Serta siswa juga akan mempunyai sikap bertanggung jawab terhadap kelompoknya.

Pemilihan model NHT dalam penelitian ini karena metode NHT memberikan lebih banyak kesempatan untuk melibatkan siswa secara aktif bekerjasama di dalam kelompok kecil, berpikir, berdiskusi hingga menyampaikan pendapatnya. Model pembelajaran NHT dapat merubah pola pembelajaran yang semula berpusat dan didominasi oleh guru (teacher-oriented) beralih pada siswa (student centered), merubah suasana kelas yang pasif menjadi aktif dan menyenangkan.

Berdasarkan hasil observasi awal yang dilakukan peneliti di SMA Negeri 3 Kabupaten Tangerang, diperlukan suatu penelitian untuk mengetahui dan membuktikan secara empiris ada atau tidaknya pengaruh model pembelajaran NHT terhadap hasil belajar sejarah di 
SMA Negeri 3 Kabupaten Tangerang.

Penelitian ini diharapkan mampu memberikan manfaat yaitu:

1. Secara teoritis hasil penelitian ini diharapkan dapat memberikan kegunaan:

a. Sebagai referensi bagi keberhasilan proses pembelajaran khususnya mata pelajaran sejarah sekaligus sebagai bahan koreksi untuk dapat meningkatkan mutu pengajaran berikutnya.

b. Untuk menambah khasanah ilmu pengetahuan memberikan informasi pentingnya penggunaan model pembelajaran yang sesuai dengan tujuan pembelajaran.

2. Secara praktis hasil penelitian ini diharapkan dapat memberikan kegunaan untuk:

a. Guru sejarah sebagai salah satu bahan alternatif agar model pembelajaran NHT dapat diterapkan di kelas dalam mewujudkan hasil belajar sejarah siswa yang maksimal sesuai dengan tujuan pembelajaran.

b. Kalangan akademis Jurusan Sejarah sebagai bahan penyusunan penelitian yang serupa dan lebih mendalam.

\section{METODE PENELITIAN}

Penelitian ini bertujuan untuk mendapatkan data empiris mengenai ada atau tidaknya pengaruh model pembelajaran NHT terhadap hasil belajar sejarah siswa SMA Negeri 3 Kabupaten Tangerang.

Penelitian ini menggunakan pendekatan kuantitatif dengan metode eksperimen untuk menguji pengaruh model pembelajaran NHT terhadap hasil belajar sejarah siswa SMA Negeri 3 Kabupaten Tangerang. Sedangkan desain penelitian menggunakan randomized control group pretest-posttest untuk memberikan gambaran dari penelitian, bentuknya sebagai berikut :

\begin{tabular}{|c|c|c|c|}
\hline Kelas & $\begin{array}{l}\text { Pre- } \\
\text { test }\end{array}$ & Perlakuan & $\begin{array}{l}\text { Post- } \\
\text { test }\end{array}$ \\
\hline Eksperimen $\left(E_{1}\right)$ & $Y_{1}$ & $x$ & $Y_{2}$ \\
\hline Kontrol $\left(E_{2}\right)$ & $Y_{1}$ & ------ & $Y_{2}$ \\
\hline
\end{tabular}

Keterangan :

E1 :Kelas eksperimen yang diberi perlakuan model pembelajaran Number Heads Together (NHT)

E2 : Kelas kontrol tanpa perlakuan model pembelajaran Number Heads Together (NHT)

$\mathrm{X}$ : Penerapan model pembelajaran Number Heads Together (NHT)

Y1 : Hasil pre-test (tes awal)

Y2 : Hasil post-test (tes akhir)

PenelitianinidilakukandiSMANegeri 3 Kabupaten Tangerang yang beralamat di Jl. Raya Curug Km. 2 Kec. Curug Kab. Tangerang. Peneliti mengambil tempat penelitian di sekolah ini, karena dalam pembelajaran sejarah guru belum pernah menggunakan model pembelajaran NHT sebelumnya. Sedangkan waktu penelitian ini berlangsung selama tujuh bulan terhitung dari bulan Maret hingga Oktober 2014.

Populasi target dalam penelitian ini adalah seluruh siswa SMA Negeri 3 Kabupaten Tangerang yang berjumlah 1007 siswa yang terdiri dari 27 kelas, sedangkan populasi terjangkau adalah 
siswa kelas X IPS yang berjumlah 190 siswa.

Pemilihan sampel dilakukan dengan teknik random sampling, diperoleh dua kelas yaitu siswa kelas X IPS 1 sebagai kelas eksperimen sebanyak 39 siswa yang diberi model pembelajaran NHT dan siswa kelas X IPS 5 sebagai kelas kontrol sebanyak 35 siswa yang diberikan metode ceramah dan diskusi kelompok.

Penelitian ini dilakukan di dua kelas yang berbeda yaitu kelas X IIS 1 sebagai kelas eksperimen (model pembelajaran NHT dan kelas X IIS 5 sebagai kelas kontrol (konvensional), dengan guru dan materi yang sama. Perbedaannya terletak pada model pembelajaran yang diberikan. Pada kelas eksperimen, siswa diberi soal pretest untuk mengetahui tingkat kemampuan siswa sebelum materi diberikan. Hasil pretest kemudian digunakan untuk membentuk kelompok-kelompok belajar, selanjutnya siswa kelas eksperimen mendapatkan model pembelajaran NHT. Sedangkan pada kelas kontrol, siswa diberikan soal pretest yang sama dengan kelas eksperimen namun pembelajaran tidak ada perubahan dari sebelumnya. Meningkatnya kemampuan siswa dalam penerapan model pembelajaran ini dapat dilihat ketika dilakukan posttest diakhir penelitian.

Instrumen yang digunakan untuk mengukur dan memperoleh data mengenai hasil belajar sejarah adalah tes sebanyak 50 butir soal pilihan ganda asosiasi. Sebelum instrumen tes hasil belajar ini diberikan kepada kelompok yang diteliti, terlebih dahulu dilakukan uji coba. Uji coba soal ini bertujuan untuk menghitung kesukaran soal, daya pembeda soal dan validitas butir soal. Teknik yang digunakan untuk menghitung taraf kesukaran soal adalah sebagai berikut :

$$
P=\frac{B}{J S}
$$

Keterangan :

$$
\begin{aligned}
& \mathrm{P}=\text { Taraf kesukaran soal } \\
& \mathrm{B}=\text { Banyaknya siswa yang } \\
& \quad \text { menjawab soal dengan benar } \\
& \text { Js }=\text { Jumlah seluruh siswa } \\
& \text { peserta tes }
\end{aligned}
$$

Tabel 2

Klasifikasi Indeks Kesukaran Soal menurut Suharsimi (2009: 213-214)

\begin{tabular}{|l|l|}
\hline Indeks Kesukar an $(P)$ & Keter angan \\
\hline $0,00-0,30$ & Sukar \\
\hline $0,30-0,70$ & Sedang \\
\hline $0,70-1,00$ & Mudah \\
\hline
\end{tabular}

Jika indeks kesukaran soal dihitung untuk mengetahui derajat kesukaran suatu tes, maka daya pembeda soal dihitung untuk mengetahui sejauh mana suatu butir soal mampu membedakan siswa yang pandai (berkemampuan tinggi) dengan siswa yang kurang pandai (berkemampuan rendah) berdasarkan kriteria tertentu. Semakin tinggi nilai daya pembeda soal suatu butir soal, semakin mampu butir soal tersebut membedakan siswa yang pandai dan siswa yang kurang pandai. Teknik ini digunakan untuk menghitung daya pembeda menggunakan rumus sebagai berikut.

$\mathrm{D}=\mathrm{B} \_\mathrm{A} / \mathrm{J} \_\mathrm{A}-\mathrm{B} \_\mathrm{B} / \mathrm{J} \_\mathrm{B}=\mathrm{P} \_\mathrm{A}-\mathrm{P} \_\mathrm{B}$

Keterangan :

$\mathrm{D}$ = Daya pembeda

JA = Jumlah siswa dari kelompok atas

$\mathrm{JB}=$ Jumlah siswa dari kelompok bawah 
$\mathrm{BA}=$ Banyaknya siswa kelompok atas yang menjawab benar

$\mathrm{BB}$ = Banyaknya siswa kelompok bawah yang menjawab benar

PA = Proporsi siswa kelompok atas yang menjawab benar

$\mathrm{PB}=$ Proporsi siswa kelompok bawah yang menjawab benar

Klasifikasi daya pembeda soal sebagai berikut:

\begin{tabular}{|c|c|}
\hline Daya Pembeda (D) & Keter angan \\
\hline $0,00-0,20$ & Jelek \\
\hline $0,20-0,40$ & Cukup \\
\hline $0,40-0,70$ & Baik \\
\hline $0,70-1,00$ & BaikSekali \\
\hline Negatif & TidakBaik \\
\hline
\end{tabular}

\section{a. Uji Validitas}

Uji validitas digunakan untuk mengetahui sejauh mana instrumen tersebut mampu mengukur apa yang akan diukur. Uji validitas dalam penelitian ini menggunakan rumus " $r$ " product moment dengan rumus :

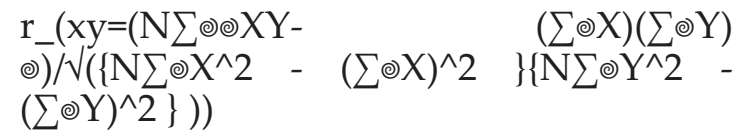

Keterangan :

rxy : Koefisien korelasi skor butir dengan skor total instrumen secara keseluruhan

$\sum X Y \quad: \quad$ Jumlah perkalian $\mathrm{x}$ dan $\mathrm{y}$

N : $\quad$ Jumlah sampel yang diuji

X : $\quad$ Jumlah skor butir $(X)$

Y $\quad: \quad$ Jumlah skor butir (Y)

\section{Uji Reliabilitas}

Uji reliabilitas dilakukan dengan teknik belah dua untuk mengetahui keajegan data. Soal dibagi menjadi dua bagian yaitu tes yang nomornya ganjil dan genap kemudian dilihat skor masingmasing dan dicari korelasinya dengan menggunakan rumus korelasi $\mathrm{r}$ product moment dari Pearson selanjutnya koefisien belah dua (Split Half) yang diperoleh dimasukkan kedalam rumus Spearman Brown untuk mencari keseluruhan. Adapun rumusnya sebagai berikut:

$$
\mathrm{r}=(2(\mathrm{rb})) /(1+\mathrm{rb})
$$

Keterangan:

$\mathrm{r}=$ reliabilitas internal seluruh instrumen

$\mathrm{rb}=$ korelasi product moment antara belahan pertama dan kedua

Hasil perhitungan reliabilitas instrumen dapat diinterpretasikan pada tabel berikut:

Tabel 4

Interpretasi Indeks Reliabilitas

\begin{tabular}{|c|c|}
\hline Reliabilitas & Keterangan \\
\hline $0,800-1,000$ & Sangat Tinggi \\
\hline $0,600-0,800$ & Tinggi \\
\hline $0,400-0,600$ & Cukup \\
\hline $0,200-0,400$ & Rendah \\
\hline $0,000-0,200$ & Sangat Rendah \\
\hline
\end{tabular}

1. Uji Prasyarat Analisis

\section{a. Uji Normalitas}

Uji normalitas digunakan untuk mengetahui apakah data populasi berdistribusi normal atau berdasarkan data sampel yang diperoleh maka dilakukan uji normalitas. Rumus yang dipakai untuk uji normalitas adalah rumus Lilliefors menurut Sudjana (2005:466) sebagai berikut:

$\mathrm{L} 0=\mathrm{F}(\mathrm{Zi})-\mathrm{S}(\mathrm{Zi})$

Keterangan : 
L0 : Observasi atau harga untuk terbesar
$\mathrm{F}(\mathrm{Zi}) \quad$ :
Peluang angka baku
$\mathrm{S}(\mathrm{Zi}) \quad$ :
Proporsi angka baku

\section{b. Uji Homogenitas}

Uji homogenitas bertujuan untuk mengetahui apakah data memiliki varian sama atau tidak. Dengan kata lain, homogenitas berarti himpunan data yang diteliti memiliki karakteristik yang sama. Maka dilakukan uji homogenitas dengan menggunakan Uji Bartlett dengan taraf signifikasi $\alpha=0,05$ untuk meyakinkan bahwa sampel berasal dari populasi yang sama.

\section{Pengujian Hipotesis}

Setelah melakukan uji prasyarat data, selanjutnya dilakukan pengajuan hipotesis dengan menggunakan rumus uji t menurut Sudjana (2005: 329) yaitu :

\begin{tabular}{|c|c|}
\hline Reliabilitas & Keter angan \\
\hline $0,800-1,000$ & Sangat Tinggi \\
\hline $0,600-0,800$ & Tinggi \\
\hline $0,400-0,600$ & Cukup \\
\hline $0,200-0,400$ & Rendah \\
\hline $0,000-0,200$ & Sangat Rendah \\
\hline
\end{tabular}

Dengan : $S^{\wedge} 2=\left(\left(n \_1-1\right) \odot S \_1 \odot^{\wedge} 2+(\right.$ n_2-1) ๑S_2®^2)/(n_1 + n_2 - 2)

$\mathrm{n} 1+\mathrm{n} 2-2=$ Derajat kebebasan

Keterangan :

$\mathrm{X} 1=$ Rata-rata selisih hasil belajar kelas eksperimen

$\mathrm{X} 2$ = Rata-rata selisih hasil belajar kelas kontrol
$\mathrm{n} 1$ = Sampel kelas eksperimen
n2 = Sampel kelas kontrol
$\mathrm{S}$ = Simpangan baku gabungan

Hipotesis Statistik
$\mathrm{H} 0: \mu 1 \leq \mu 2$ @ Tidak terdapat pengaruh model pembelajaran Number Heads Together (NHT) terhadap hasil belajar sejarah.

$\mathrm{H} 1: \mu 1>\mu 2 @ \quad$ Terdapat pengaruh model pembelajaran Number Heads Together (NHT) terhadap hasil belajar sejarah.

Keterangan :

$\mu 1$ @ rata-rata hasil belajar kelas eksperimen yang diberi model pembelajaran Number Heads Together (NHT)

$\mu 2$ () rata-rata hasil belajar kelas kontrol yang tidak diberi model pembelajaranNumber Heads Together (NHT)

Pengujian hipotesis nol ( $\mathrm{HO}$ ) dilakukan dengan tingkat kepercayaan 95\% yang secara statistik dinyatakan dengan $\alpha=$ 0,05 . Kriteria pengujiannya adalah $\mathrm{H} 0$ ditolak apabila thitung $>\mathrm{t}$ tabel $=0,05$

\section{HASIL PENELITIAN DAN PEMBAHASAN}

Hipotesismenyatakan bahwa terdapat perbedaan hasil belajar antara siswa yang diberikan model pembelajaran kooperatif tipe NHT dengan siswa yang diberikan metode pembelajaran konvensional.

Hasil Penelitian ini menunjukan nilai rata-rata kelas eksperimen lebih besar dari pada kelas kontrol, dengan harga $\mathrm{t}$ sebesar 5,961 pada taraf signifikasi 0,05 . Hasil pengujian menunjukan, $\mathrm{H} 0$ ditolak dan $\mathrm{H} 1$ diterima sehingga dapat diinterpretasikan bahwa hasil belajar kelas eksperimen lebih besar dari pada kelas kontrol sehingga dapat disimpulkan bahwa terdapat pengaruh penggunaan model pembelajaran NHT terhadap hasil belajar Sejarah kelas X IIS di SMA Negeri 3 Kabupaten Tangerang.

Berdasarkan data dari perhitungan variablel penelitian ini, yaitu hasil dari nilai tes hasil belajar kelas eksperimen dan kelas kontrol, maka diperoleh data 
hasil penelitian meliputi nilai terendah, nilai tertinggi, dengan nilai rata-rata, simpangan baku dan varians sebagai berikut:

Tabel 6

Deskripsi data penelitian

\begin{tabular}{|c|c|c|}
\hline Variabel & $\begin{array}{c}\text { Kelas } \\
\text { Eksperimen }\end{array}$ & $\begin{array}{c}\text { Kelas } \\
\text { Kontrol }\end{array}$ \\
\hline $\begin{array}{c}\text { Nilai } \\
\text { Terendah }\end{array}$ & 19 & 12 \\
\hline $\begin{array}{c}\text { Nilai } \\
\text { Tertinggi }\end{array}$ & 41 & 35 \\
\hline Ratarata & 29,85 & 22,94 \\
\hline Varians & 23,55 & 26,06 \\
\hline $\begin{array}{c}\text { Simpangan } \\
\text { Baku }\end{array}$ & 4,85 & 5,10 \\
\hline
\end{tabular}

1. Data Hasil Belajar Kelas Eksperimen

Dibawah ini disajikan distribusi frekuensi grafik dan histogram.Data perhitungan hasil belajar pada kelas eksperimen.

\section{Tabel 7}

Distribusi Hasil Belajar Kelas Eksperimen

\begin{tabular}{|c|c|c|c|c|c|}
\hline Kelas Interval & $\begin{array}{c}\text { Batas } \\
\text { Bawah }\end{array}$ & Batas Atas & Frek. Absolut & Frek. Relatif \\
\hline 19 & -22 & 18.5 & 22.5 & 4 & $10.26 \%$ \\
\hline 23 & -26 & 22.5 & 26.5 & 7 & $17.95 \%$ \\
\hline 27 & -30 & 26.5 & 30.5 & 6 & $15.38 \%$ \\
\hline 31 & -34 & 30.5 & 34.5 & 18 & $46.15 \%$ \\
\hline 35 & -38 & 34.5 & 38.5 & 3 & $7.69 \%$ \\
\hline 39 & -42 & 38.5 & 42.5 & 1 & $2.56 \%$ \\
\hline \multicolumn{2}{|c|}{ Jumlah } & & & 39 & $100 \%$ \\
\hline
\end{tabular}

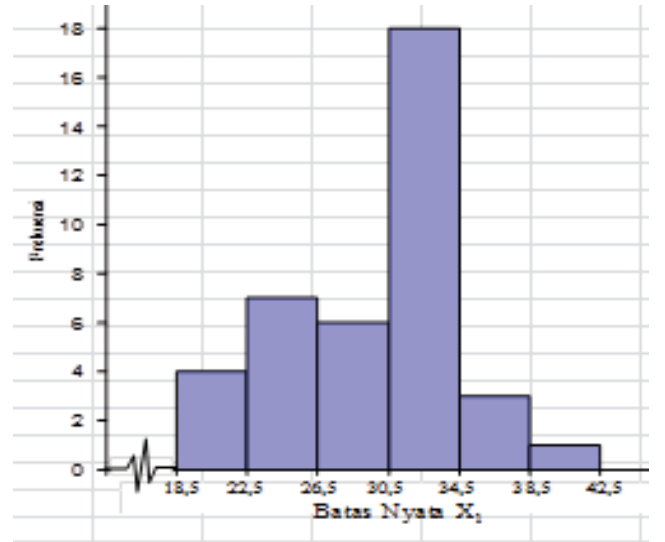

Berdasarkan tabel grafik tersebut diatas memperlihatkan bahwa frekuensi data tertinggi di kelas interval 31-34 yaitu sebesar 18. Frekuensi tersebut berada di titik tengah 32,5 . Sedangkan data terendah pada kelas interval 25-28 yaitu sebesar 1 . Frekuensi tersebut berada di titik tengah 26,5 .

\section{Data Hasil Belajar Kelas Kontrol}

Dibawah ini disajikan distribusi frekuensi grafik dan histogram. Data perhitungan hasil belajar pada kelas kontrol.

\section{Tabel 8}

Distribusi Hasil Belajar Kelas Kontrol

\begin{tabular}{|c|c|c|c|c|c|c|}
\hline \multicolumn{3}{|c|}{ Kelas Interval } & \multirow{2}{*}{\begin{tabular}{|c|}
$\begin{array}{c}\text { Batas } \\
\text { Bawah }\end{array}$ \\
11.5 \\
\end{tabular}} & \multirow{2}{*}{$\begin{array}{c}\begin{array}{c}\text { Batas } \\
\text { Atas }\end{array} \\
15.5 \\
\end{array}$} & \multirow{2}{*}{\begin{tabular}{|c} 
Frek. Absolnt \\
3 \\
\end{tabular}} & \multirow{2}{*}{$\begin{array}{c}\text { Frek Rehtif } \\
8.57 \% \\
\end{array}$} \\
\hline 12 & - & 15 & & & & \\
\hline 16 & - & 19 & 15.5 & 19.5 & 9 & $25.71 \%$ \\
\hline 20 & - & 23 & 19.5 & 23.5 & 6 & $17.14 \%$ \\
\hline 24 & - & 27 & 23.5 & 27.5 & 10 & $28.57 \%$ \\
\hline 28 & - & 31 & 27.5 & 31.5 & 6 & $17.14 \%$ \\
\hline 32 & - & 35 & 31.5 & 35.5 & 1 & $2.86 \%$ \\
\hline \multirow{2}{*}{\multicolumn{3}{|c|}{ Juniah }} & & & 4 & \\
\hline & & & & & 35 & $100 \%$ \\
\hline
\end{tabular}

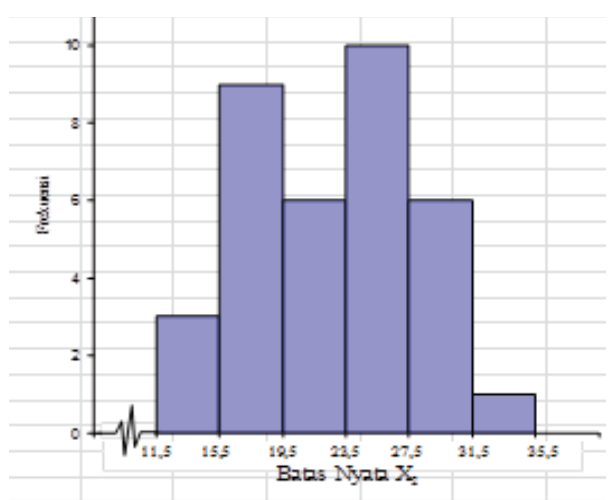


Berdasarkan tabel dan grafik tersebut diatas memperlihatkan bahwa frekuensi data tertinggi di kelas interval 24-27 yaitu sebesar 10. Frekuensi tersebut berada di titik tengah 25,5. Sedangkan data terendah pada interval 32-35 yaitu sebesar 1 . Frekuensi tersebut berada dititik tengah 33,5 .

\section{Grafik 3}

Grafik Perbandingan Hasil Belajar Kelas Eksperimen dan Kontrol

Kelas Eksperimen
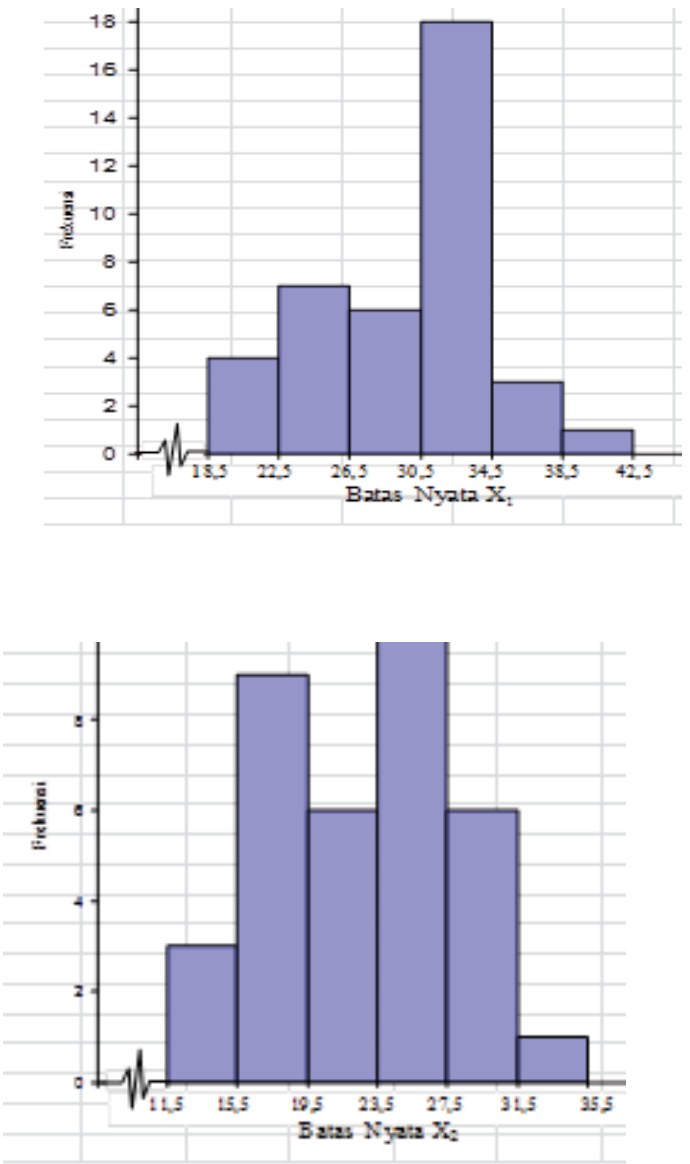

Sebelum data dianalisis untuk pengujian hipotesis, diperlukan pemeriksaan data atau pengujian analisis terhadap data tersebut yang meliputi uji normalitas dan uji homogenitas.

Eksperimen diperoleh Lhitung $<$ Ltabel yaitu $0,132<0,142$ pada taraf kepercayaan $95 \%(\alpha=0,05)$ dan jumlah sampel 39, maka H0 : sebaran data kelas eksperimen normal diterima. Data yang berasal dari kelas. kontrol diperoleh Lhitung $<$ Ltabel yaitu $0,145<0,150$. Pada taraf kepercayaan $95 \%(\alpha=0,05)$ dan jumlah sampel 35, makaH0 : sebaran data kelas kontrol normal diterima.

\section{Uji Normalitas}

Dalam penelitian ini digunakan uji normalitas menggunakan rumus Lilliefors. Berdasarkan uji normalitas pada data yang berasal dari kelas eksperimen diperoleh Lhitung $<$ Ltabel yaitu $0,132<0,142$ pada taraf kepercayaan 95\% $(\alpha=0,05)$ dan jumlah sampel 39, maka $\mathrm{H} 0$ : sebaran data kelas eksperimen normal diterima. Data yang berasal dari kelas. kontrol diperoleh Lhitung $<$ Ltabel yaitu $0,145<0,150$. Pada taraf kepercayaan $95 \% \quad(\alpha=0,05)$ dan jumlah sampel 35, makaH0 : sebaran data kelas kontrol normal diterima.

Kesimpulan bahwa sampel kelas eksperimen dan kelas kontrol berdistribusi normal karena data hasil belajar kelas eksperimen dan kontrol merupakan sebaran data yang normal.

\section{Uji Homogenitas}

Pengujianhomogenitas variansikedua kelas dilakukan dengan menggunakan uji Barlett. Berdasarkan perhitungan, pada data pretest dan posttest diperoleh ๑2 2hitung < (2) tabel pada taraf kepercayaan $95 \%(\alpha=0,05)$ dan derajat bebas $=1$ yaitu $0,091<3,84$, maka varians homogen diterima. Kesimpulan bahwa data hasil belajar kelas eksperimen dan kelas kontrol berasal dari populasi yang homogeny karena mempunyai varians yang sama.

Pengujian Hipotesis nol (H0) dilakukan dengan tingkat kepercayaan $95 \%$ yang secara statistic dinyatakan dengan $\alpha=0,05$. Kriteria pengujiannya adalah $\mathrm{H} 0$ ditolak apabila thitung $<$ ttabel. 
$\mathrm{H} 0: \mu 1 \leq \mu 2$ ๑Tidak terdapat pengaruh model pembelajaran Number Heads Together (NHT) terhadap hasil belajar sejarah.

H1: $\mu 1>\mu 2$ ๑Terdapat pengaruh model pembelajaran Number Heads Together (NHT) terhadap hasil belajar sejarah.

Setelah diuji menggunakan uji-t diperoleh harga 5,961 artinya lebih besar dari harga t pada tabel sebesar 2,00 pada taraf kepercayaan $95 \%(\alpha=0,05)$, maka H0 ditolak dan $\mathrm{H} 1$ diterima.

Hasil Penelitian ini menunjukan nilai rata-rata kelas eksperimen lebih besar dari pada kelas kontrol, dengan harga t sebesar 5,961 pada taraf signifikasi 0,05 . Hasil pengujian menunjukan, H0 ditolak dan $\mathrm{H} 1$ diterima sehingga dapat diinterpretasikan bahwa hasil belajar kelas eksperimen lebih besar dari pada kelas kontrol sehingga dapat disimpulkan bahwa terdapat pengaruh penggunaan model pembelajaran Number Heads Together (NHT) terhadap hasil belajar Sejarah kelas X IIS di SMA Negeri 3 Kabupaten Tangerang.

Penelitian ini memiliki banyak kekuranga, yaitu : 1). Masih adanya siswa yang memiliki rasa takut untuk mengutarakan pendapatnya. Ketakutan ini biasanya didasarkan pada tekanan teman-teman satu kelompoknya, apabila jawaban siswa tersebut salah, 2). Masih adanya siswa yang belum optimal dalam mengerjakan tugas pada lembar kerja kelompok pada saat diskusi. Sehingga membuat siswa tidak siap apabila diminta guru dalam menjelaskan dan mengutarakan jawabannya, 3.) Suasana kelas yang cenderung ramai pada saat diskusi sehingga guru terkadang sulit mengatur kelas untuk kondusif kembali.

\section{KESIMPULAN, IMPLIKASI DAN SARAN}

Berdasarkan perhitungan dan pengujian hipotesis dalam penelitian ini ialah, bahwa terdapat pengaruh postitif penggunaan model pembelajaran kooperatif tipe NHT yang dilakukan secara berkala terhadap hasil belajar sejarah di SMA N 3 Kabupaten Tangerang pada kelas X IIS 1 sebagai kelas eksperimen.

Pengaruh tersebut terlihat dengan peningkatan hasil belajar sejarah pada siswa yaitu dari nilai pretest dan posttest. Guru yang mengembangkan model pembelajaran NHT di dalam kelas, membuat siswa terlibat aktif dalam pembelajaran dan lebih berani mengutarakan pendapatnya. Maka, diperoleh kesimpulan bahwa terdapat pengaruh model pembelajaran NHT terhadap hasil belajar sejarah di SMA Negeri 3 Kabupaten Tangerang.

Penelitian ini berimplikasi bahwa penggunaan model pembelajaran kooperatif tipe NHT dapat meningkatkan hasil belajar siswa dan membuat siswa terlibat aktif dalam pembelajaran. Hal paling mendasar yang dituntut dalam proses pembelajaran adalah keaktifan siswa. Karena keaktifan siswa dalam proses pembelajaran akan menyebabkan interaksi yang tinggi antara guru dengan siswa atau pun siswa dengan siswa. Hal ini akan mengakibatkan suasana kelas menjadi segar dan kondusif, dimana masing-masing siswa dapat melibatkan kemampuannya semaksimal mungkin. Aktivitas belajar yang timbul dari siswa akan mengakibatkan terbentuknya pengetahuan dan keterampilan yang akan mengarah pada peningkatan prestasi dan berdampak pada peningkatan mutu pendidikan. Sehingga hal yang perlu 
diterapkan dalam pembelajaran di kelas haruslah berorientasi pada studentcentered.

Berdasarkan pemaparan kesimpulan dan implikasi, peneliti memberikan beberapa saran:

Pertama : Bagi guru dapat menggunakan metode pembelajaran STAD guna meningkatkan hasil belajar sejarah siswa SMA.

Kedua : Bagi guru yang belum mengerti tentang metode STAD sebaiknya Kepala Sekolah memberikan pelatihan-pelatihan.

Ketiga : Bagi siswa yang memiliki kecerdasan interpersonal rendah guru dapat menggunakan Metode pembelajaran STAD sebagai salahsatu metode alternatif dalam proses pembelajaran.

Keempat : Bagi siswa yang memiliki kecerdasan interpersonal rendah guru dapat menggunakan Metode pembelajaran STAD sebagai salah satu metode alternatif dalam proses pembelajaran.

\section{DAFTAR PUSTAKA}

Arikunto, Suharsimi. Dasar-Dasar Evaluasi Pendidikan. Jakarta : Bumi Aksara, 2009.

Hamdani. Strategi Belajar Mengajar. Bandung: Pustaka Setia, 2011.
Isjoni. Cooperative Learning: Efektivitas Pembelajaran Kelompok. Bandung: Alfabeta, 2007.

Kuntowijoyo. Pengantar Ilmu Sejarah. Yogyakarta : Benteng Budaya, 2005.

Lie, Anita. Cooperative Learning. Jakarta: Grasindo, 2005.

Sanjaya, Wina. Strategi Pembelajaran Berorientasi Standar Proses Pendidikan. Jakarta: Kencana Prenada Media, 2006.
Sudjana, Nana. Penilaian Hasil Proses Belajar Mengajar. Bandung: Remaja Rosdakarya, 2006.

Trianto. Mendesain Model Pembelajaran InovatifProgresif. Jakarta: Kencana Prenada Media Group, 2009.

Wineburg, Sam. Berpikir Historis, Terj. Masri Maris. Jakarta: Yayasan Obor Indonesia, 2006.

Jurnal:

Subakti, Y.R. Paradigma Pembelajaran Sejarah Berbasis Konstruktivisme. Jurnal Historia Vitae Universitas Sanata Dharma Vol. 24 No.1 April 2010. 